\title{
PROSEDUR PEMBERIAN KREDIT PT. BANK PEMBANGUNAN DAERAH (BPD) SUMATERA BARAT
}

\author{
Indah Mulia, Afriyeni \\ Akademi Keuangan dan Perbankan Padang \\ Afriyeni.yen@gmail.com
}

\begin{abstract}
ABSTRAK
Tujuan dari penelitian adalah untuk mengetahui Prosedur Pemberian Kredit PT. Bank Pembangunan Daerah (BPD) Sumatera Barat. Dalam menganalisa data, penulis menggunakan metode analisa data kualitatif sebagai metode penelitian yang menjelaskan secara deskriptif mengenai prosedur pemberian kredit pada PT. BPD Sumatera Barat. PT. BPD Sumatera Barat merupakan bank milik pemerintah daerah. Tujuan pendiriannya tidak hanya dilandasi oleh tujuan komersial semata, melainkan lebih banyak didorong oleh rasa kebangsaan yang tinggi dan hasrat yang kuat untuk membangkitkan semangat serta kemampuan golongan ekonomi lemah khususnya golongan pribumi, agar mereka mampu mengembangkan usahanya dan menunjang jiwa kewiraswastaan serta menunjang stabilitas ekonomi dan pembangunan nasional pada umumnya dan daerah pada khususnya. PT. BPD Sumatera Barat merupakan lembaga keuangan yang mempunyai peranan yang besar dalam menunjang pertumbuhan ekonomi bangsa dan pembangunan terutama di daerah Sumatera Barat. PT. BPD Sumatera Barat telah menyalurkan kredit sesuai dengan ketentuan dan prosedur yang telah ditetapkan yaitu mulai dari pengenalan dan pendekatan kepada calon debitur, tahap permohonan kredit, analisa kredit, tahap persetujuan kredit sampai tahap realisasi kredit. Untuk menghindari resiko yang terjadi dari kredit yang diberikan PT. BPD Sumatera Barat melakukan pengawasan mulai dari permohonan kredit pengumpulan data, survei lapangan, pembuatan studi kelayakan, commite kredit, realisasi kredit, administrasi kredit hingga pelunasan kredit.
\end{abstract}

Kata Kunci: Prosedur, Kredit

\section{LATAR BELAKANG}

Perbankan mempunyai tugas yang sangat penting dalam rangka mendorong pencapaian tujuan nasional yang berkaitan dalam peningkatan dan pemerataan taraf hidup masyarakat dan peningkatan kelangsungan perekonomian Indonesia. Pertumbuhan ekonomi harus diarahkan untuk meningkatkan pendapatan masyarakat serta mengatasi ketimpangan ekonomi dengan kesenjangan sosial. Pertumbuhan ekonomi guna meningkatkan pendapatan masyarakat, perlu diberikan perhatian bagi usaha-uaha untuk membina dan melindungi usaha kecil dan tradisional serta golongan ekonomi lemah. Hal ini bukan hanya dalam meningkatkan produksi saja tetapi juga untuk mencegah 
melebarnya jurang pemisah antara kaya dan miskin sehingga tercipta masyarakat yang adil dan makmur, sesuai dengan tujuan pembangunan di Indonesia.

Bank merupakan lembaga keuangan yang dibangun atas dasar kepercayaan. Menurut Undang-undang No. 7/1992 menyebutkan bahwa bank adalah badan usaha yang menghimpun dana dari masyarakat dalam bentuk simpanan dan menyalurkan kepada masyarakat dalam rangka meningkatkan taraf hidup rakyat banyak. Peranan bank dalam mendukung kegiatan perekonomian cukup besar karena bank memberikan jasa dalam lalu lintas peredaran uang. Dilihat dari fungsi utama sebuah bank adalah sebagai lembaga yang dalam aktivitas usahanya menghimpun dan menyalurkan dana masyarakat. Salah satu cara penyaluran dana tersebut adalah melalui kebijakan kredit yang dilakukannya. Menurut UU No. 10 tahun 1998 tentang perbankan kredit adalah penyediaan dan atau tagihan yang dapat dipersamakan dengan itu, berdasarkan persetujuan atau kesepakatan pinjam meminjam antara bank dengan pihak lain yang mewajibkan pihak meminjam untuk melunasi hutangnya setelah jangka waktu tertentu dengan pemberian bunga.

Kredit pada umumnya timbul karena manusia mempunyai kebutuhan dan keinginan untuk menghasilkan atau memperoleh barang dan jasa yang melebihi kemampuan dana yang dimilikinya. Agar dapat memenuhi kebutuhan tersebut, maka ia perlu mendapatkan kredit (pinjaman) dari pihak-pihak lain baik itu dari orang lain maupun dari lembaga keuangan seperti bank.

Dalam proses penyaluran kredit tentunya memiliki tahapan analisis yang tidak sederhana. Setelah mendapatkan nasabah yang prospek, pihak bank akan melakukan berbagai analisis seperti analisis kuantitatif, kualitatif, analisis jaminan, serta cheking Bank Indonesia yang semuanya dilakukan untuk meminimalkan resiko. Analisis kredit meliputi latar belakang nasabah atau perusahaan, prospek usahanya, jaminan yang diberikan serta faktor-faktor lainnya.

Prosedur penyaluran kredit yang sehat ialah bahwa setiap calon debitur harus memberikan keyakinan dari berbagai aspek bahwa dirinya dapat mengembalikan kedit (pokok dan bunga) tepat pada waktunya. Apabila karena sesuatu hal kemudian ternyata debitur tidak dapat memenuhi kewajibannya, maka bank akan menyita jaminan dalam nilai yang cukup untuk membayar hutang pokok dan bunganya. Melalui pernyataan tersebut dapat diambil kesimpulan bahwa bank harus teliti dalam menyalurkan kredit.

Dalam penyaluran kredit bank akan menghadapi berbagai macam situasi seperti jika debitur tidak membayar kewajibannya tepat pada waktunya, debitur menghilang dan sebagainya. Oleh sebab itu perlu dilakukan pengawasan terhadap pelaksanaan kredit.

Sebelum debitur memperoleh kredit terlebih dahulu harus melalui tahapantahapan penilaian yaitu mulai dari permohonan calon debitur, penelitian data oleh bagian kredit, memeriksa kelengkapan data, wawancara, tinjauan langsung ke lapangan, analisa kredit, keputusan kredit, perjanjian kredit, dan pengikatan agunan. Tahapan-tahapan dalam memberikan kredit ini di kenal sebagai prosedur pemberian kredit. Tujuan prosedur pemberian kredit adalah untuk memastikan kelayakan suatu kredit diterima atau ditolak. 
PT. Bank Pembangunan Daerah sumatera Barat (BPD) adalah salah satu lembaga keuangan yang memberikan fasilitas kredit terhadap masyarakat. Masyarakat dapat memanfaatkan fasilitas layanan ini untuk meminjam uang yang nantinya dapat digunakan sesuai dengan tujuan awal peminjaman. Keberadaan PT. BPD Sumatera Barat sendiri sebagai suatu lembaga keuangan yang mempunyai fungsi memberikan pelayanan perbankan dan membantu dalam meningkatkan taraf hidup masyarakat memberikan manfaat yang besar baik dalam hal penghimpunan dana maupun penyaluran dana kepada masyarakat. Dengan adanya PT. BPD Sumatera Barat ini diharapkan dapat memberikan manfaat yang optimal kepada masyarakat dalam rangka meningkatkan taraf hidup rakyat banyak.

Berdasarkan uraian dari penjelasan diatas penulis tertarik untuk melakukan penelitian terhadap PT. BPD Sumatera Barat dengan judul "Prosedur Pemberian Kredit Pada PT. Bank Pembangunan Daerah (BPD) Sumatera Barat".

\section{METODE PENELITIAN}

Dalam pengumpulan data dan bahan untuk melakukan penelitian ini di gunakan metode - metode pengumpulan data, sebagai berikut :

Metode pengumpulan data

a. Studi Lapangan (Field Research)

Peninjauan langsung ke objek penelitian yang dipilih untuk meneliti hasil data primer. Penelitian langsung ke lapangan ini akan dapat membantu penulis untuk melengkapi data yang diperlukan. Adapun cara riset lapangan ini adalah dengan mewawancarai langsung pihak-pihak yang berkepentingan dalam hal ini adalah perusahaan atau instansi yang terkait.

b. Studi Perpustakaan. (Library Research)

Penelitian yang dilakukan ke perpustakaan berupa buku-buku ilmiah dan tulisan-tulisan yang berhubungan dengan pembahasan yang dilakukan.

Metode Analisa Data

Dalam menganalisa data, penulis menggunakan metode analisa data kualitatif sebagai metode penelitian yang menjelaskan secara deskriptif mengenai prosedur pemberian kredit pada PT. BPD Sumatera Barat.

\section{TINJAUAN LITERATUR \\ Pengertian Bank}

Menurut Undang - Undang Negara Republik Indonesia Nomor 10 Tahun 1998 tentang perbankan, yang dimaksud dengan bank adalah badan usaha yang menghimpun dana dari masyarakat dalam bentuk simpanan dan menyalurkannya kepada masyarakat dalam bentuk kredit dan atau bentuk-bentuk lainnya yang dalam rangka meningkatkan taraf hidup rakyat banyak.

Dari pengertian diatas dapat disimpulkan bahwa usaha perbankan meliputi tiga kegiatan, yaitu menghimpun dana, menyalurkan dana, dan memberikan jasa bank lainnya. Kegiatan menghimpun dana, berupa mengumpulkan dana dari masyarakat dalam bentuk simpanan giro, tabungan dan deposito. Kegiatan menyalurkan dana, berupa pemberian pinjaman kepada masyarakat. Sedangkan 
jasa-jasa perbankan lainnya diberikan untuk mendukung kelancaran kegiatan utama tersebut.

Menurut undang-undang pokok perbankan nomor 7 tahun 1992 dan ditegaskan lagi dengan keluarnya undang-undang RI nomor 10 tahun 1998 maka jenis perbankan terbagi dua jenis, yaitu:

1. Bank Umum

Yaitu bank yang melaksanakan kegiatan usaha secara konvensional dan atau berdasarkan prinsip syariah yang dalam kegiatannya memberikan jasa dalam lalu lintas pembayaran. Institusi keuangan yang berorientasi laba. Untuk memperoleh laba tersebut bank umum melaksanakan fungsi intermediasi. Karena diizinkan mengumpulkan dana dalam bentuk deposito, bank umum disebut juga sebagai lembaga keuangan depositori. Berdasakan kemampuannya menciptakan uang (giral), bank umum dapat juga disebut sebagai bank umum pencipta uang giral.

2. Bank Perkreditan Rakyat (BPR)

Yaitu bank yang melaksanakan kegiatan usahanya secara konvensional atau berdasarkan prinsip syariah yang dalam

Fungsi dan kegiatan bank kegiatannya tidak memberikan jasa dalam lalu lintas pembayaran.

Fungsi-fungsi bank:

1) Sebagai tempat untuk penitipan atau penyimpanan uang

Bank memberikan surat atau selembar kertas dalam bentuk sebagai:

a) Rekening koran atau giro

Yaitu simpanan yang setiap saat dapat diminta kembali atau dipergunakan untuk melakukan pembayaran dengan mempergunakan cek (perintah pembayaran). Kalau kita menyimpan uang dalam bentuk ini biasanya tidak mendapatkan penghasilan dalam bentuk "bunga".

b) Deposito berjangka

Yaitu simpanan yang dititipkan ke bank untuk jangka waktu tertentu, misalnya 1,2,3,12 bulan. Dalam artian bahwa uang tersebut dapat dipergunakan kalau waktu yang telah ditetapkan telah tiba. Dan untuk simpanan bentuk ini biasanya bank membayar bunga pada yang punya uang (karena bank merasa dapat menggunakan uang tersebut dalam usahanya).

c) Tabungan

Pada hakikatnya sama dengan time deposit, tetapi tabungan mempunyai persyaratan tertentu yang berbeda dengan time deposit.

2) Sebagai lembaga pembeli atau penyalur kredit

Dalam hal ini bank dapat memanfaatkan uang yang disimpan oleh nasabah pada bank tersebut dikarenakan tidak semua orang sekaligus datang berbondong-bondong ke bank untuk mengambil uangnya kembali. Pemanfaatan uang tersebut dilakukan dengan menyalurkannya pada pihak yang membutuhkan kredit atau dibelikannya surat-surat berharga yang menghasilkan tingkat bunga. 
3) Sebagai perantara dalam lalu lintas pembayaran

Bank bertindak sebagai penghubung antara nasabah yang satu dengan yang lainnya jika keduanya melakukan transaksi. Dalam hal ini kedua orang tersebut tidak secara langsung melakukan pembayaran tetapi cukup memerintahkan pada bank untuk menyelesaikannya.

Secara keseluruhan fungsi bank adalah:

1) Mengumpulkan dana yang sementara menganggur untuk dipinjamkan pada pihak lain atau membeli surat-surat berharga.

2) Mempermudah didalam lalu lintas pembayaran uang.

3) Menjamin keamanan uang masyarakat yang sementara tidak digunakan, misalnya menghindari resiko hilang, kebakaran dan lainlain.

4) Menciptakan kredit

Kegiatan bank umum :

a) Menambah dan mengurangi jumlah uang diperedaran.

b) Menunjang kelancaran mekanisme pembayaran dalam masyarakat.

c) Mengumpulkan dana dari masyarakat.

d) Pemberian kredit.

e) Penyediaan jasa dalam perdagangan internasional

f) Jasa pialang surat berharga

g) Jasa penitipan barang berharga dan surat bernilai

\section{Jenis-jenis bank}

Jenis perbankan dapat ditinjau dari beberapag segi antara lain:

1. Dilihat dari segi sifatnya

a) Bank devisa

Merupakan bank yang dapat melaksanakan transaksi keluar negeri atau yang berhubungan dengan mata uang asing secara keseluruhan. Persyaratan untuk menjadi bank devisa ini ditentukan oleh Bank Indonesia setelah memenuhi semua persyaratan yang ditetapkan.

b) Bank non devisa

Merupakan bank yang belum mendapatkan izin untuk melaksanakan transaksi sebagai bank devisa, sehingga tidak melaksanakan transaksi seperti halnya bank devisa, dimana transaksi yang dilakukan masih dalam batas-batas negara.

2. Dilihat dari segi fungsinya

a) Bank umum

Yaitu bank yang melaksanakan kegiatan usahanya secara konvensional atau berdasarkan prinsip syariah yang dalam kegiatannya memberikan jasa dalam lalu lintas pembayaran.

b) Bank perkreditan rakyat (BPR)

Yaitu bank yang melaksanakan kegiatan usahanya secara konvensional atau berdasarkan prinsip syariah yang dalam kegiatannya tidak memberikan jasa dalam lalu lintas pembayaran. 
3. Dilihat dari segi kepemilikannya

a) Bank milik pemerintah

Yaitu bank yang baik akte pendiriannya maupun modalnya dimiliki oleh pemerintah, sehingga seluruh keuntungan bank ini dimiliki oleh pemerintah pula.

b) Bank milik swasta nasional

Yaitu bank yang seluruh atau sebagian besarnya dimiliki oleh swasta nasional serta akte pendiriannya pun didirikan oleh swasta, begitu pula pembagian keuntungannya diambil oleh swasta pula.

4. Dilihat dari segi cara menetukan harga

a) Bank yang berdasarkan prinsip konvensional

Merupakan suatu bank yang menetapkan bunga sebagai harga jual baik untuk produk simpanan, maupun produk pinjaman. Penentuan harga ini dikenal dengan istilah spread based.

b) Bank yang berdasarkan prinsip syariah

Yaitu menerapkan aturan perjanjian berdasarkan hukum islam antara bank dengan pihak lain baik dalam hal untuk menyimpan dana atau pembiayaan usaha atau kegiatan lainnya yang dikenal dengan prinsip bagi hasil.

\section{Pengertian kredit}

Secara etimologi, istilah kredit berasal dari bahasa latin, yaitu "credere", yang berarti percaya atau credo atau creditum yang berarti saya percaya. Dengan demikian dasar dari kredit adalah kepercayaan.

Berdasarkan Undang-Undang No.7 tahun 1992 dan telah diperbaharui menjadi Undang-Undang No.10 tahun 1998 pasal 1 ayat 11 yang dimaksud dengan kredit adalah penyediaan uang atau tagihan yang dapat dipersamakan dengan itu, berdasarkan persetujuan atau kesepakatan yang mewajibkan pinjam meminjam antar bank dengan pihak lain yang mewajibkan pihak peminjam untuk melunasi hutangnya setelah jangka waktu tertentu dengan jumlah bunga imbalan atau pembagian hasil keuntungan.

Didalam pemberian kredit terdapat dua pihak yang langsung berkaitan. Yang pertama pihak pemberi kredit (kreditor) yaitu pihak yang mempunyai kelebihan dana dan yang kedua pihak penerima kredit (debitur) yaitu pihak yang membutuhkan dana.

Bank merupakan lembaga financial intermediary berperan aktif sebagai perantara dari kedua belah pihak tersebut. Bank menghimpun dana dari masyarakat yang kelebihan dana dalam bentuk simpanan dan kemudian menyalurkannya kembali kepada masyarakat dalam bentuk kredit atau yang dipersamakan dengan itu secara efektif melalui sektor usaha yang produktif. Sebagai lembaga perantara bank diharapkan mampu turut serta meningkatkan taraf kehidupan masyarakat secara khusus dan peningkatan perekonomian secara umum.

\section{Fungsi dan tujuan pemberian kredit}

Fungsi kredit perbankan dalam kehidupan perekonomian dan perdagangan antara lain sebagai berikut:

1) Kredit pada hakekatnya dapat meningkatkan daya guna uang 
2) Kredit dapat meningkatkan peredaran dan lalu lintas uang.

3) Kredit pada hakekatnya dapat meningkatkan daya guna barang

4) Kredit sebagai salah satu alat kebijakan pemerintah untuk stabilisasi perekonomian.

5) Kredit dapat meningkatkan kegiatan usaha.

6) Kredit dapat meningkatkan pemerataan pendapatan.

7) Kredit sebagai alat hubungan ekonomi internasional.

Tujuan pokok dari pemberian kredit oleh suatu bank adalah untuk:

1) Turut mensukseskan program pemerintah dibidang ekonomi dan pembangunan.

2) Meningkatkan aktivitas ekonomi atau kegiatan perusahaan agar dapat menjalankan fungsinya guna menjamin terpenuhinya kebutuhan masyarakat.

3) Memperoleh laba karena pemberian kredit merupakan kegiatan utama bank dan penghasilan pokok bank.

\section{Unsur-unsur dan jenis - jenis kredit}

Unsur-unsur yang terdapat dalam pemberian kredit antara lain:

a) Kepercayaan (trust)

Yaitu keyakinan si pemberi kredit bahwa kredit yang diberikannya benar-benar akan diterimanya kembali dalam jangka waktu tertentu dimasa yang akan datang.

b) Waktu (time)

Yaitu suatu masa yang memisahkan antara pemberian prestasi dengan kontra prestasi yang akan diterimanya pada masa yang akan datang.

c) Tingkat resiko

Yaitu suatu tingkat resiko yang akan dihadapi sebagai akibat adanya jangka waktu yang memisahkan antara pemberian prestasi dengan kontra prestasi yang akan diterimanya di kemudian hari. Semakin lama kredit yang diberikan semakin tinggi pula tingkat resikonya, karena sejauh masih selalu terdapat unsur ketidaktentuan yang tidak dapat diperhitungkan. Inilah yang menyebabkan timbulnya unsur resiko. Dengan adanya unsur ini maka timbullah jaminan dalam pemberian kredit.

d) Prestasi

Prestasi atau objek kredit tidak saja diberikan dalam bentuk uang, tetapi juga dapat berbentuk barang atau jasa.

Jenis-jenis kredit yaitu:

a) Kredit investasi

Merupakan kredit jangka menengah dan panjang yang ditujukan untuk modal usaha pembelian sarana alat produksi dan atau pembelian barang modal berupa aktiva tetap atau investasi

b) Kredit modal kerja

Merupakan kredit jangka pendek atau menengah yang ditujukan untuk memberikan modal usaha seperti antara lain pembelian bahan baku atau barang yang akan diperdagangkan. 
c) Kredit konsumsi

Merupakan kredit untuk perorangan yang ditujukan untuk pembelian suatu barang yang digunakan untuk kepentingan perseorangan (pribadi).

d) Kredit usaha tanpa bunga dan agunan

Merupakan kredit yang disediakan khusus untuk usaha kecil dan menengah. Kredit semacam ini sangat meringankan bagi pengusaha.

\section{Prinsip-prinsip pemberian kredit}

Di dalam pemberian kredit, dapat ditinjau prinsip-prinsip dalam pemberian kredit yaitu:

a) Prinsip kepercayaan

Karena kredit berarti kepercayaan, maka dalam hal pemberian kredit pun haruslah ada kepercayaan dari kreditur bahwa dana tersebut akan bermanfaat bagi debitur dan kepercayaan dari kreditur bahwa debitur dapat mengembalikan dana tersebut dalam jangka waktu tertentu.

b) Prinsip kehati-hatian

Agar kredit atau pembiayaan tidak menjadi macet, maka dalam memberikan kredit atau pembiayaan haruslah cukup kehati hatian dari pihak kreditur dengan menganalisis dan mempertimbangkan semua faktor yang relevan. Untuk itu perlu dilakuan suatu pengawasan terhadap suatu pemberian kredit.

c) Prinsip sinkronisasi

Prinsip sinkronisasi (matching) merupakan prinsip yang mengharuskan adanya sinkronisasi antara pinjaman dan asset/income dari debitur. Misalnya, jangan memberikan kredit/pembiayaan jangka pendek untuk keperluan investasi jangka panjang.

d) Prinsip kesamaan valuta

Dalam hal ini yang dimaksudkan adalah sedapat-dapatnya ada kesamaan antara jenis valuta untuk kredit/pembiayaan dan penggunaan dana tersebut, sehingga resiko fluktuasi mata uang dapat dihindari.

e) Prinsip perbandingan antara pinjaman dan modal

Dalam hal ini yang dimaksud adalah perbandingan antara pinjaman dan modal dalam rasio yang wajar.

f) Prinsip perbandingan antara pinjaman dan asset

Dalam hal ini yang dimaksud adalah perbandingan antara pinjaman dan asset dalam rasio yang wajar.

Selain itu menurut Lukman Dendawijaya (2008:91), dasar penilaian kredit yang sering dipakai didunia perbankan dikenal dengan prinsip 5C, yang terdiri dari:

1) Character (watak)

Yaitu suatu keyakinan bahwa sifat atau watak dari orang-orang yang diberikan kredit benar-benar dapat dipercaya, hal ini tercermin dari latar belakang debitur baik yang bersifat latar belakang pekerjaan maupun bersifat pribadi seperti gaya hidup, kebiasaan, dan social standingnya. 
2) Capacity (kapasitas)

Untuk melihat nasabah dalam kemampuannya dalam bidang bisnis dihubungkan dengan pendidikannya, kemampuan bisnis juga diukur dengan kemampuannya dalam memahami tentang ketentuan-ketentuan pemerintah. Begitu pula dengan kemampuannya dalam menjalankan usahanya selama ini. Pada akhirnya akan terlihat kemampuannya dalam mengembalikan kredit yang disalurkan.

3) Capital (permodalan)

Untuk melihat penggunaan modal apakah efektif atau tidak, dilihat dari laporan keuangan (neraca dan laporan laba-rugi) dengan melakukan pengukuran seperti segi likuiditas, solvabilitas, rentabilitas, dan ukuran lainnya. Capital juga harus dilihat dari sumber mana saja modal yang ada sekarang ini.

4) Collateral (agunan/jaminan)

Merupakan jaminan yang diberikan calon nasabah baik yang bersifat fisik maupun non fisik. Jaminan hendaknya melebihi jumlah kredit yang diberikan, jaminan juga harus diteliti keabsahannya sehingga jika terjadi suatu masalah, maka jaminan yang dititipkan akan dapat dipergunakan secepat mungkin.

5) Condition of economic (kondisi ekonomi)

Dalam menilai kredit hendaknya juga dinilai kondisi ekonomi dan politik sekarang dan dimasa yang akan datang sesuai sektor masing-masing serta prospek usaha dari sektor usaha yang debitur jalankan. Penilaian prospek bidang usaha yang dibiayai hendaknya benar-benar memiliki prospek yang baik sehingga kemungkinan kredit tersebut bermasalah relatif kecil.

Selain 5C diatas, ada juga prinsip lain dalam memberikan kredit yaitu yang biasa disebut 4P, yaitu:

1) Personality

Bank mencari data tentang kepribadian si peminjam seperti riwayat hidupnya (kelahiran, pendidikan, pengalaman, usaha/pekerjaan dan sebagainya), hobinya, keadaan keluarga (istri, anak), social standing (pergaulan dalam masyarakat serta bagaimana pendapat masyarakat tentang si peminjam), serta hal-hal lain yang erat hubungannya dengan kepribadian si peminjam.

2) Purpose

Mencari data tentang tujuan atau keperluan penggunaan kredit. Apakah akan digunakannya untuk berdagang, berproduksi atau membeli rumah. Dan apakah tujuan penggunaan kredit itu sesuai dengan line of bussiness kredit bank yang bersangkutan. Misalnya, keperluan/tujuan kredit untuk perkapalan sedangkan line of business bank justru dalam bidang pertanian.

3) Prospect

Yang dimaksud dengan prospect adalah harapan masa depan dari bidang usaha atau kegiatan usaha si peminjam. Ini dapat diketahui dari perkembangan usaha si peminjam selama beberapa bulan/tahun, perkembangan keadaan ekonomi perdagangan, keadaan ekonomi/perdagangan sektor usaha si peminjam, kekuatan keuangan 
perusahaan yang di buat dari earning power (kekuatan pendapatan/keuntungan) masa lalu dan perkiraan masa mendatang.

4) Payment

Mengetahui bagaimana pembayaran kembali pinjaman yang diberikan. Hal ini dapat diperoleh dari perhitungan tentang prospek kelancaran penjualan dan pendapatan sehingga dapat diperkirakan kemampuan pengembalian pinjaman ditinjau dari waktu serta jumlah pengembaliannya.

\section{Kolektibilitas kredit}

Di dalam pemberian kredit perlu dilakukan pengawasan kredit. Tujuan dari pengawasan kredit ini adalah untuk menghindari resiko-resiko kredit yang mungkin timbul dan untuk menilai tingkat kualitas kredit yang di berikan. Ada beberapa tingkat kolektibilitas dalam pemberian kredit, yaitu:

1) lancar

Yaitu kredit yang pembayarannya tepat waktu dan perkembangan rekening debitur dalam keadaan baik, tidak terdapat tunggakan serta sesuai dengan perjanjian kredit.

2) Dalam perhatian khusus

Yaitu kredit yang terdapat tunggakan pokok dan/atau bunga s.d 90 hari

3) Kurang lancar

Yaitu kredit yang terdapat tunggakan pokok dan/atau bunga s.d diatas 90 hari s.d 120 hari

4) Diragukan

Yaitu kredit yang terdapat tunggakan pokok dan/atau bunga s.d 120 hari s.d 180 hari.

5) Macet

Yaitu kredit yang terdapat tunggakan pokok dan/atau bunga diatas 180 hari.

\section{Prosedur pemberian kredit}

Sebelum debitur memperoleh kredit terlebih dahulu harus melalui tahapantahapan penilaian mulai dari pengajuan proposal kredit dan dokumen-dokumen yang diperlukan, pemeriksaan keaslian dokumen, analisis kredit sampai dengan kredit dikucurkan. Tahapan-tahapan dalam memberikan kredit ini kita kenal dengan prosedur pemberian kredit. Tujuan prosedur pemberian kredit adalah untuk memastikan kelayakan suatu kredit, diterima atau ditolak. Dalam menentukan kelayakan suatu kredit maka dalam setiap tahap selalu dilakukan penilaian yang mendalam.

Prosedur dalam pemberian kredit dalam dunia perbankan antara bank yang satu dengan bank lainnya sebenarnya tidak jauh berbeda. Perbedaannya mungkin hanya terletak pada persyaratan yang ditetapkan masing-masing bank dan tujuan dari pemberian kredit tersebut.

Pada PT. Bank Pembangunan Daerah (BPD) Sumatera Barat Cabang utama Padang, proses pemberian kredit kepada nasabah adalah sebagai berikut: 
1) Nasabah mengajukan permohonan kredit lengkap dengan dokumendokumen pendukung (perizinan, laporan keuangan, data identitas, akta perusahaan, data penjualan, data agunan, dll).

2) Permohonan tersebut diproses setelah data-data yang diperlukan lengkap. Proses dimulai dengan meminta data informasi debitur secara on-line ke bank Indonesia. Melakukan kunjungan ke lokasi usaha (on the spot), wawancara, dan penilaian agunan (taksasi).

3) Kemudian dilakukan analisis/penilaian kelayakan kredit (5C) oleh petugas analis kredit berdasarkan data yang telah diperoleh dan hasil kunjungan ke lokasi serta wawancara. Analisis tersebut dituangkan dalam suatu laporan penilaian kredit yang dikenal juga dengan appraisal kredit atau rekomendasi kredit.

4) Apabila usaha dinilai layak oleh analisi kredit setelah dilakukan analisis, maka appraisal kredit akan diajukan untuk disetujui oleh pemimpin cabang atau pemimpin divisi, atau direksi (tergantung wewenang persetujuan mengacu kepada nominal kredit yang akan dimintakan persetujuannya).

5) Apabila telah disetujui maka diberikan surat pemberitahuan persetujuan kredit (SP2K) kepada nasabah yang mencantumkan syarat-syarat dan ketentuan yang harus dipenuhi oleh nasabah. Jika nasabah menyetujui persyaratannya maka SP2K ditandatangani oleh nasabah dan diserahkan kembali pada bank.

6) Proses selanjutnya adalah realisasi kredit, pengikatan agunan kredit, dan pencairan kredit.

7) Setelah pencairan kredit dilakukan maka BPD Sumbar akan melakukan monitoring terhadap kredit yang telah diberikan tersebut. Monitoring dilakukan dengan cara mengunjungi nasabah, memonitor aktivitas rekening, menelepon nasabah, mencari informasi lain dari rekananrekanan nasabah, dll.

Tahapan -tahapan dalam pemberian kredit

1. Persyaratan dokumen permohonan kredit

a. Perorangan :

1) Foto Copy kartu tanda penduduk / paspor / SIM calon debitur, penjamin dan pemilik agunan.

2) Foto Copy NPWP.

3) Foto Copy bukti kepemilikan agunan.

4) Surat keterangan hubungan keluarga dari instansi yang berwenang bagi agunan yang kepemilikannya bukan atas nama debitur.

5) Foto copy izin usaha dan tempat izin usaha untuk jenis kredit modal kerja.

6) Foto copy surat nikah atau kartu keluarga, bagi yang telah menikah

7) Pas foto calon debitur suami / istri, bagi yang telah menikah

b. Badan usaha/badan hukum:

1) Foto Copy kartu tanda penduduk / paspor / SIM pengurus, penjamin, dan pemilik agunan.

2) Foto Copy anggaran dasar dan seluruh akta perubahan.

3) Foto Copy izin usaha dan izin tempat usaha dan lainnya yang dimiliki. 
4) Foto Copy NPWP.

5) Laporan keuangan (neraca, rugi/laba dan sebagainya.

6) Foto Copy bukti kepemilikan agunan.

7) Surat keterangan hubungan keluarga dari instansi yang berwenang bagi agunan yang kepemilikannya bukan atas nama calon debitur.

8) Dokumen lainnya yang dipersyaratkan sesuai dengan ketentuan yang berlaku, seperti laporan keuangan yang telah di adult akuntan publik, penilaian agunan oleh penilai atau konsultan independen, dan lainnya.

c. Pemerintah :

1) Foto Copy kartu tanda penduduk / paspor / SIM dari kepala daerah atau pejabat yang berwenang.

2) Surat persetujuan DPRD, untuk debitur pemerintah daerah.

3) Foto Copy NPWP kepala daerah, untuk debitur pemerintah daerah.

4) Dokumen lainnya yang dipersyaratkan sesuai dengan ketentuan yang berlaku.

d. Lainnya :

Mempedomani undang-undang dan/atau peraturan pemerintah yang berlaku.

2. Identifikasi data

Identifikasi permohonan kredit dilakukan dengan mempedomani buku pelaksanaan kredit (PPK) tentang proses persetujuan kredit.

3. Dipertimbangkan untuk dilanjutkan

Setelah identifikasi data dilakukan, maka selanjutnya pihak bank akan melakukan pertimbangan. Apabila calon nasabah tersebut di luar kriteria yang ditentukan oleh bank, maka permohonan langsung ditolak. Sedangkan apabila calon nasabah termasuk dalam kriteria yang dapat dilayani, maka permohonan akan dipertimbangkan untuk dilanjutkan.

4. Kelengkapan data

Dalam tahap ini semua data tentang calon debitur akan diperiksa keasliannya. Hal-hal yang diperiksa yaitu seperti : identitas pemohon, jumlah kredit, tujuan penggunaan kredit, nilai agunan / jaminan, dan hal hal lainnya yang berhubungan dengan pemohon.

5. Wawancara

Dalam tahap ini pihak bank langsung mewawancarai si pemohon. Selain pertimbangan data melalui tulisan, pertimbangan melalui lisan pun diperlukan. Dengan wawancara ini bisa dilakukan analisis 5C, yaitu untuk mengetahui karakter si pemohon, apakah si pemohon adalah seorang yang dapat dipercaya atau tidak, pihak pewawancara tentunya telah memiliki pengalaman yang cukup untuk menilai karakter si pemohon.

6. Informasi

Dalam tahap ini pihak bank berusaha mencari informasi kepada orang orang terdekat si pemohon seperti kerabat, teman dekat maupun tetangga dari si pemohon. Pihak bank langsung bertanya kepada pihak-pihak tersebut mengenai kehidupan keseharian dari si pemohon, dengan pernyataan dari orang - orang terdekat si pemohon tersebut maka akan membantu pihak bank dalam memberikan putusan kredit. 
7. Tinjauan setempat ke lokasi

Dalam tahap ini pihak bank melakukan tinjauan langsung ke lokasi pemohon, pihak bank akan mengidentifikasi kesesuaian data antara pernyataan si pemohon dengan fakta dilapangan.

8. Analisis kelayakan kredit

Analisis kredit dilakukan untuk menilai kelayakan suatu permohonan kredit dan memperkirakan faktor-faktor risiko yang akan timbul berkaitan dengan pemberian kredit. Untuk mengetahui seberapa jauh risiko yang mungkin akan timbul maka dilakukan analisis aspek - aspek dalam pemberian kredit.

Aspek minimal yang harus dianalisis pada appraisal / rekomendasi kredit antara lain:

1) Latar belakang

Dalam latar belakang harus diungkapkan secara jelas identitas surat permohonan, maksud permohonan, tujuan penggunaan, jumlah permohonan, jangka waktu, jenis fasilitas, rencana sumber pembayaran kembali dan informasi lainnya.

2) Data pokok

Pada data pokok diuraikan dan digambarkan identitas diri pemohon, nama istri pemohon dan nama ibu kandung pemohon.

3) Aspek hukum

a) Legalitas pemohon

Analisis terhadap legalitas pemohon ditujukan untuk memastikan kecakapan dan kewenangan pemohon untuk mengajukan permohonan dan mengadakan perjanjian kredit dengan bank.

b) Legalitas usaha

Analisis terhadap legalitas usaha pemohon yang ditunjukkan dengan surat keterangan usaha dari pihak yang berwenang.

4) Aspek manajemen

Dalam pembahasan ini dituangkan secara ringkas data tentang:

a) Hubungan pemohon dengan bank (Tabungan, Deposito, Kredit)

b) Lama menetap di kediaman terakhir

c) Pengalaman berusaha.

d) Administrasi dan pembukuan usaha.

5) Aspek Teknis

Dalam pembahasan ini dituangkan secara ringkas data tentang :

a) Lokasi usaha

b) Objek / komoditi yang diusahakan.

c) Siklus usaha

d) Fasilitas produksi yang tersedia

e) Barang modal yang akan dibiayai

6) Aspek pemasaran

Dalam pembahasan ini dituangkan secara ringkas data tentang :

a) Jenis barang dagang atau produk yang dipasarkan.

b) Konsumen

c) Wilayah pemasaran. 
d) Sistem pemasaran

e) Omset penjualan.

f) Rencana peningkatan penjualan

7) Aspek keuangan

Dalam pembahasan ini dituangkan secara ringkas data tentang :

a) Analisis kemampuan membayar (repayment capacity) meliputi ;

a. Penerimaan usaha per bulan

b. Penerimaan lainnya per bulan

c. Biaya usaha per bulan

d. Biaya hidup per bulan

e. Penghasilan bersih per bulan

f. Angsuran kredit per bulan

g. Sisa penghasilan per bulan

b) Cara pembayaran kredit

c) Sumber-sumber lain yang dapat digunakan untuk pembayaran kredit

8) Aspek agunan

Aspek agunan merupakan faktor penting yang perlu diperhatikan dalam analisis kredit untuk itu dalam aspek agunan dituangkan secara ringkas :

a) Agunan dan pengikatannya

b) Nilai dan ratio agunan

c) Penjamin kredit

d) Asuransi jiwa

e) Asuransi agunan

f) Asuransi kredit, bila ada

9) Aspek sosial ekonomi

Dalam pembahasan ini dituangkan secara ringkas data tentang:

a) Dampak kredit terhadap kesinambungan usaha

b) Mutu produk

c) Efisiensi usaha

d) Tenaga kerja yang diserap

9. Wewenang dan keputusan kredit

Wewenang keputusan kredit mengacu kepada ketentuan yang berlaku sesuai dengan tingkat kewenangan yang ditetapkan dengan keputusan direksi. Keputusan kredit oleh pejabat pemutus kredit adalah berupa keputusan disetujui atau ditolak. Apabila kredit disetujui, maka selanjutnya akan dibuatkan surat keputusan kredit, namun apabila kredit yang di ajukan tidak disetujui maka selanjutnya akan di buatkan surat penolakan.

10. Surat persetujuan kredit

Dalam surat persetujuan kredit harus dicantumkan batas waktu kepada pemohon untuk memberikan persetujuan / penolakan. Apabila dalam jangka waktu tersebut pemohon tidak memberikan jawaban, maka permohonan kredit yang sudah memperoleh persetujuan dianggap batal. Sedangkan apabila pemohon menyetujui persyaratan dan ketentuan yang terkandung dalam surat ptusan kredit, maka pemohon harus 
menandatangani surat putusan tersebut diatas materai dan mengembalikan ke bank.

11. Perjanjian kredit

Penandatanganan perjanjian kredit atau akad pembiayaan berikut seluruh perjanjian tuntutannya, dilaksanakan setelah debitur menandatangani SP2K bermaterai cukup dan telah diserahkan kembali kepada bank.

Dalam hal tertentu menurut pertimbangan bank seperti nominal kredit yang relatif besar dan / atau permasalahan hukum yang relatif kompleks, maka perjanjain atau akad pembiayaan dapat dilakukan secara notarial akta.

Dalam perjanjian kredit harus tertera beberapa hal diantaranya:

a) Maksimum kredit

Jumlah yang tertera dalam maksimum kredit ini adalah jumlah tertinggi yang diizinkan kepada sipenerima kredit. Jumlah ini berdasarkan perhitungan kalkulasi kredit dalam aspek finansial. Maksimum kredit ini juga sering disebut dengan line of credit.

b) Jangka waktu

Untuk kredit jangka pendek, jangka waktu yang diberikan paling lama untuk pemakaian satu tahun. Berarti kredit dapat juga diberikan untuk jangka waktu 3 bulan, 6 bulan, atau 9 bulan atau beberapa bulan saja asal tidak melebihi satu tahun.

c) Keperluan kredit

Keperluan kredit harus sesuai dengan bidang usaha debitur, berdasarkan target produktivitas yang akan dicapainya. Tentang target ini harus dijelaskan secara terperinci.

d) Bunga / provisi

Penetapan tentang bunga ini adalah sesuai dengan penentuan interest policy. Provisi kredit adalah suatu beban yang dikenakan kepada debitur sebagai akibat dari perjanjian kredit yang dibuat. Biasanya provisi kredit ditetapkan sebesar $1 \%$ dari jumlah maksimum kredit. Provisi tersebut harus dibayar secara kontan oleh debitur (penerima kredit) pada saat perjanjan ditandatangani, demikian pula apabila oleh karena sesuatu dan lain hal kredit tersebut diperpanjang jangka waktunya.

e) Bea materai

Sesuai dengan ketentuan bea materai tahun 1921, maka setiap pemberian kredit dikenakan bea sebesar 0,50\% dari maksimum kredit yang diberikan / diterima. Jumlah tersebut selanjutnya disetorkan ke kas negara. Bilamana memang diperlukan dan berdasarkan pertimbangan-pertimbangan khusus, menteri keuangan dapat menentukan lain dari ketentuan di atas, misalnya terhadap jenis kredit tertentu, dibebaskan dari kewajiban pembayaran bea materai.

f) Bentuk kredit

Dalam perkembangan perbankan sekarang ini, bentuk pinjaman rekening koranlah yang lazim digunakan oleh bank-bank, oleh karena hal tersebut akan lebih memperlonggar debitur dalam menggunakan 
/memanfaatkan kredit baik dalam bentuk uang kartal maupun uang giral. Bank juga dapat memperoleh manfaat dalam perputaran keuangan debitur yang tersalur dalam rekening tersebut, disamping sebagai cara pengawasan yang efektif terhadap kelancaran keuangan debitur

g) Jaminan kredit

Dalam jaminan atau agunan harus dikemukakan secara terperinci, seperti jumlah jaminan, nilai jaminan dan status pemiliknya. Nilai agunan harus sesuai dengan penetapan taksasi bank. Biasanya agunan ini bersama-sama dengan cara pengikatannya seperti hipotek, gadai, surat kuasa menjual, merupakan lampiran dari akad kredit (perjanjian kredit) dan merupakan bagian yang tidak terpisahkan dari bagiankredit tersebut.

h) Asuransi

Setiap jaminan kredit sebaiknya diasuransikan sesuai dengan sifat jaminan tersebut, hal ini dimaksudkan untuk mengamankan risiko bilamana terjadi hal-hal yang tidak diinginkan seperti kebakaran dan lain sebagainya.

i) Ketentuan-ketentuan tambahan

Di luar ketentuan-ketentuan pokok tersebut diatas, bank dapat menetapkan ketentuan-ketentuan tambahan, dan ketentuan tersebut dicantumkan pula sebagai pasal tambahan dalam perjanjian kredit.

12. Pengikatan agunan

Setelah putusan dan persetujuan kredit di buat dan disetujui, maka langkah selanjutnya adalah pengikatan agunan/jaminan. Dengan adanya pengikatan ini maka agunan /jaminan telah menjadi hak bank. Apabila terjadi permasalahan yang membuat debitur tidak mampu mengembalikan uang yang dipinjamnya, maka bank berhak mengambil alih agunan/jaminan tersebut untuk selanjutnya menjadi milik bank.

13. Surat penolakan

Surat penolakan ini di buat oleh bank untuk memberitahukan pada calon debitur bahwa kredit yang di ajukan tidak dapat disetujui oleh bank. Halhal yang menyebabkan kredit tidak di setujui dapat berupa tidak adanya kecocokan antara pernyataan calon debitur dengan fakta di lapangan, kurang lengkapnya data yang diberikan calon debitur, dan sebagainya.

14. Dikembalikan kepada nasabah

Setelah di buatkan surat penolakan oleh bank, selanjutnya akan di serahkan pada calon debitur beserta dokumen-dokumen yang telah diserahkan oleh calon debitur kepada bank akan di serahkan kembali kepada calon debitur tersebut.

\section{Kredit bermasalah}

Yang dimaksud dengan kredit bermasalah adalah:

1) Kredit yang dalam pelaksanaannya belum mencapai/memenuhi target yang diinginkan oleh pihak bank.

2) Memiliki kemungkinan timbulnya resiko dikemudiaan hari bagi bank dalam arti luas. 
3) Mengalami kesulitan di dalam menyelesaikan kewajiban baik dalam bentuk pembayaran kembali pokoknya dan atau pembayaran bunga, denda keterlambatan (kondisional tergantung situasi) menjadi beban Nasabah yang bersangkutan.

Terdapat 2 faktor penyebab kredit bermasalah, yaitu :

a) Faktor intern

a. Analisis kredit atau kredit yang tidak akurat

b. Lemahnya pengawasan dan monitoring

c. Kredit diberikan secara terkonsentrasi baik jumlah maupaun penerimaannya

d. Lemahnya SDM (Sumber Daya Manusia)

b) Faktor ekstern

a. Nasabah menyalahgunakan kredit yang diperolehnya

b. Faktor kesulitan usaha yang di alami nasabah

Prosedur penyelesaian kredit bermasalah :

a) Upaya yang dilakukan secara administrasi adalah nasabah diberi surat tunggakan, surat peringatan I, surat peringatan II, dan surat peringatan III.

b) Selain itu dilakukan penagihan langsung kepada nasabah, keluarga nasabah, pemilik agunan ( jika pemilik agunan adalah pihak lain seperti orang tua, anak, kakek, saudara, dll).

c) Jika belum ada penyelesaian konkrit dari pihak nasabah atau pemilik agunan, maka proses dilanjutkan dengan meminta bantuan penagihan dari pihak lain seperti kejaksaan atau balai lelang swasta.

d) Jika nasabah bersedia dapat dilakukan penjualan agunan dibawah tangan ( tanpa pelelangan) untuk menyelesaikan kreditnya.

e) Jika nasabah tidak bersedia jual agunan dibawah tangan maka langkah terakhir adalah dengan melakukan pelelalngan agunan kredit untuk penyelesaian tunggakan kredit nasabah.

\section{KESIMPULAN}

Berdasarkan uraian pada bab-bab sebelumnya, maka dapat diambil kesimpulan sebagai berikut:

a. PT. BPD Sumatera Barat merupakan bank milik pemerintah daerah. Tujuan pendiriannya tidak hanya dilandasi oleh tujuan komersial semata, melainkan lebih banyak didorong oleh rasa kebangsaan yang tinggi dan hasrat yang kuat untuk membangkitkan semangat serta kemampuan golongan ekonomi lemah khususnya golongan pribumi, agar mereka mampu mengembangkan usahanya dan menunjang jiwa kewiraswastaan serta menunjang stabilitas ekonomi dan pembangunan nasional pada umumnya dan daerah pada khususnya.

b. PT. BPD Sumatera Barat merupakan lembaga keuangan yang mempunyai peranan yang besar dalam menunjang pertumbuhan ekonomi bangsa dan pembangunan terutama di daerah Sumatera Barat.

c. Struktur organisasi PT.BPD Sumatera Barat dalam melakukan aktivitas usahanya merupakan struktur organisasi yang berbentuk organisasi garis dan staf. 
d. PT. BPD Sumatera Barat telah menyalurkan kredit sesuai dengan ketentuan dan prosedur yang telah ditetapkan yaitu mulai dari pengenalan dan pendekatan kepada calon debitur, tahap permohonan kredit, analisa kredit, tahap persetujuan kredit sampai tahap realisasi kredit.

e. Untuk menghindari resiko yang terjadi dari kredit yang diberikan PT. BPD Sumatera Barat melakukan pengawasan mulai dari permohonan kredit pengumpulan data, survei lapangan, pembuatan studi kelayakan, commite kredit, realisasi kredit, administrasi kredit hingga pelunasan kredit.

\section{DAFTAR PUSTAKA}

Afriyeni, A. (2019). Mekanisme Transaksi Dan Sistem Perhitungan Bunga Kredit Usaha Mikro Kecil Dan Menengah (UMKM) Pada PT. Pegadaian (Persero) Cabang Ulak Karang. https://doi.org/10.17605/OSF.IO/WB2E6

Alanshari, F., \& Marlius, D. (2018). Prosedur Pemberian Kredit KPR Pada PT. Bank Tabungan Negara (Persero) TBK Cabang Pembantu Bukittinggi. https://doi.org/10.31227/osf.io/rsfhc

Amelia, L., \& Marlius, D. (2018). Pengendalian Kredit Dalam Upaya Menciptakan Bank Yang Sehat Pada PT. Bank Pembangunan Daerah Sumatera Barat Cabang Utama Padang. https://doi.org/10.31227/osf.io/kpc64

Bank Pembangunan Daerah Sumatera Barat. (2013). Sejarah berdirinya, visi dan misi, struktur organisasi, ruang lingkup usaha dan peraturan pelaksanaan kredit PT BPD Sumatera Barat

Bambang Tri Cahyono.(1983). Manajemen perkreditan. Ananda, Yogyakarta

Darmawanto, \& Fernos, J. (2019). Prosedur Pemberian Kredit Pada Bank Nagari Cabang Sijunjung. https://doi.org/10.31227/osf.io/psqfy

Dendawijaya, Lukman. (2008). Manajemen Perbankan, Gramedia Indonesia, Jakarta

Djumhana, Muhamad. 2000. Hukum Perbankan di Indonesia. Bandung : PT. Citra Aditya Bakti

Kasmir. (2006). manajemen perbankan. PT. Raja Grafindo Persada, Jakarta

Kasmir. (2011). Bank dan lembaga keuangan lainnya. PT. Raja Grafindo Persada: Jakarta

Mulyadi. 2001.sistem akuntansi. Universitas Gajah Mada. Yogyakarta : Salemba Empat 
Orlando, A., \& Susanto, R. (2019). Mekanisme Pencairan Kredit Usaha Rakyat Pada PT. Bank Rakyat Indonesia Unit Lubuk Buaya. https://doi.org/10.31219/osf.io/zuv2y

Pratama, D., \& Fernos, J. (2019). Prosedur Pelaksanaan Kredit Usaha Rakyat (KUR) Pada PT. Bank Nagari Cabang Padang. https://doi.org/10.31227/osf.io/ag68j

Sinungan. Muchdarsyah,( 1985). "dasar-dasar dan teknik manajemen kredit" Bina aksara, Jakarta.

Sinungan. Muchdarsyah. (1997). “ manajemen dana bank”. Edisi kedua, PT. Bumi aksara, Jakarta

Thomas suyatno dkk,(1995), "dasar-dasar perkreditan". Edisi keempat, PT. Gramedia Pustaka Utama, Jakarta.

Undang-undang no 10 tahun 1998, "tentang perbankan", sinar grafika, jakarta 2002.

Warman Djohan, (2000), kredit bank, PT. Mutiara Sumber Widya, Jakarta

Widayati, R. (2019). Aktivitas Pemberian Kredit Komersil Pada Bank Nagari Cabang Sijunjung. https://doi.org/10.17605/OSF.IO/QTVZ9

Widayati, R. (2019). Pelaksanaan Kredit Pada Bank Perkreditan Rakyat LPN Pasar Baru Durian Sawahlunto. https://doi.org/10.17605/OSF.IO/5HPAB

Widayati, R. (2019). Aktivitas Pemberian Kredit Usaha Pada PT. Bank Perkreditan Rakyat Batang Kapas. https://doi.org/10.17605/OSF.IO/EDPN4 